\title{
Study on the morphology and thermomechanical properties of poly(urethane-siloxane) networks based on hyperbranched polyester
}

\author{
Marija V. Pergal ${ }^{1}$, Jasna V. Džunuzović ${ }^{1}$, Milena Špírková ${ }^{2}$, Rafal Poręba ${ }^{2}$, Miloš Steinhartt, \\ Miodrag M. Pergal ${ }^{4}$, Sanja Ostojić ${ }^{5}$ \\ ${ }^{1}$ Institute of Chemistry, Technology and Metallurgy (ICTM) - Center of Chemistry, University of Belgrade, Belgrade, \\ Serbia \\ ${ }^{2}$ Institute of Macromolecular Chemistry AS CR, v.v.i. (IMC), Nanostructured Polymers and Composites Department, \\ Prague, Czech Republic \\ ${ }^{3}$ Institute of Macromolecular Chemistry AS CR, v.v.i. (IMC), Supramolecular Polymer Systems Department, Prague, \\ Czech Republic \\ ${ }^{4}$ Faculty of Chemistry, University of Belgrade, Belgrade, Serbia \\ ${ }^{5}$ Institute of General and Physical Chemistry, University of Belgrade, Belgrade, Serbia
}

\begin{abstract}
Two series of polyurethane films based on hyperbranched polyester of the second pseudogeneration (Boltorn $\left.{ }^{\circledR}\right), 4,4^{\prime}$-methylenediphenyl diisocyanate and two different siloxane prepolymers, $\alpha, \omega$-dihydroxy-(ethylene oxide-poly(dimethylsiloxane)-ethylene oxide) (EO-PDMS-EO) and $\alpha, \omega$-dihydroxypropyl-poly(dimethylsiloxane) (HP-PDMS), were prepared by two-step polymerization in solution. The influence of the type and content of soft segment on the morphology, thermomechanical and surface properties of the synthesized polyurethanes was studied by atomic force microscopy (AFM), small-angle X-ray scattering (SAXS), scanning electron microscopy (SEM), dynamic mechanical thermal analysis (DMTA) and water absorption measurements. It was found that these techniques confirmed existence of microphase separated morphology. Synthesized polyurethanes exhibited two glass transition temperatures and one second relaxation process. The results showed that polyurethanes based on HP-PDMS had higher surface roughness, better microphase separation and waterproof performances. Samples synthesized with lower PDMS content had less hydrophobic surface, but higher crosslinking density and better thermomechanical properties.
\end{abstract}

Keywords: polyurethane networks, poly(dimethylsiloxane), hyperbranched polyester, morphology, thermomechanical properties.

Available online at the Journal website: http://www.ache.org.rs/HI/
Polymers

SCIENTIFIC PAPER

UDC 678.664:678.674:66

Hem. Ind. 67 (6) 871-879 (2013)

doi: 10.2298/HEMIND130225022P
Polyurethane (PU) networks have different applications, especially in the coatings industry, because of their specific properties such as good mechanical flexibility, toughness, chemical resistance, high gloss and high abrasion resistance [1,2]. The properties of PU networks are remarkably affected by the content, type and molecular weight of the soft segments and type of the crosslinking agent. Generally, mixed or special types of macrodiols as soft segments are used to impart specific physical properties of PU networks.

Poly(dimethylsiloxane) (PDMS) has a unique combination of properties, such as low-temperature flexibility, high thermal and thermo-oxidative stabilities, good biocompatibility, low surface energy, ultraviolet resistance and high permeability to many gases $[3,4]$. How-

Correspondence: M.V. Pergal, Institute of Chemistry, Technology and Metallurgy - Center of Chemistry, University of Belgrade, Njegoševa 12, 11000 Belgrade, Serbia.

E-mail:marijav@chem.bg.ac.rs

Paper received: 25 February, 2013

Paper accepted: 21 March, 2013 ever, pure PDMS has weak mechanical properties, which limit its application, except in the case when PDMS is crosslinked and reinforced with adequate fillers. The non-polar nature of the PDMS structure combined with very low intermolecular interactions is responsible for its thermodynamical incompatibity with almost all organic polymers. This is reflected by the very low value of the solubility parameters of PDMSs ( $\delta$ ranges 14.9-15.3 $\left.\left(\mathrm{J} / \mathrm{cm}^{3}\right)^{1 / 2}\right)$, when compared with other polymers $\left(\delta\right.$ ranges $\left.17.5-28.6\left(\mathrm{~J} / \mathrm{cm}^{3}\right)^{1 / 2}\right)$. This is the most important driving force in the formation of microphase separated morphology of PDMS containing polyurethanes. Furthermore, the low glass transition temperature of PDMS also provides ideal conditions for the formation of phase-segregated polymer morphologies [3]. In many cases, a siloxane molecular weight as low as $500-600 \mathrm{~g} / \mathrm{mol}$ (6-8 siloxane repeat units) and an organic segment having only a single repeat unit is sufficient to obtain microphase separated morphology. The morphology of multiphase polymer system plays an important role in the final properties of the PU 
networks based on PDMS. In the last few years, PDMS has been used in PUs synthesis to improve the properties such as thermal stability, adhesive strength, shape memory properties and water resistance of PUs [5-8]. In addition, it has been shown that the adequate incorporation of the PDMS into PUs can impart some good properties, simultaneously avoiding appearance of unwanted macroscopic phase separation during the polymerization, without significant altering the good mechanical properties of PU networks [6-10].

Hyperbranched polyesters (HBPs) have recently attracted considerable attention as crosslinkers for PU networks preparation due to their specific three-dimensional structure, large number of end functional groups and interesting properties such as high solubility in different solvents, low degree of chain entanglements in melt, low viscosity in solution and in melt and good compatibility with other materials [11-14]. In our previous works, it has been shown that a combination of commercially available hydroxyl-functional HBPs (Boltorn ${ }^{\circledR}$ ), PDMS macrodiol and aromatic diisocyanate can be used for the synthesis of PUs with good thermal and mechanical properties [15-18]. During the synthesis of PU samples, HBP with its numerous end $-\mathrm{OH}$ groups provides fast curing and formation of the highly crosslinked material with good mechanical properties and chemical resistance. On the other hand, the presence of PDMS improves thermal and surface properties and brings elasticity in this highly crosslinked material. The aim of this paper is to examine the effects of the type and content of PDMS on the morphology, surface and thermomechanical properties of the prepared materials using atomic force microscopy (AFM), smallangle X-ray scattering (SAXS), scanning electron microscopy (SEM), water absorption measurement and dynamic mechanical thermal analysis (DMTA).

\section{EXPERIMENTAL PART}

\section{Materials}

$\alpha, \omega$-Dihydroxy-(ethylene oxide-poly(dimethylsiloxane)-ethylene oxide) (EO-PDMS-EO) and $\alpha, \omega$-dihydroxypropyl-poly(dimethylsiloxane) (HP-PDMS) were supplied by $A B C R$ and dried over molecular sieves (0.4 $\mathrm{nm}$ ) before use. The number average molecular weights, $M_{n}$, of the EO-PDMS-EO and HP-PDMS were calculated from the ${ }^{1} \mathrm{H}-\mathrm{NMR}$ spectroscopy results. The $M_{\mathrm{n}}$ of the prepolymer EO-PDMS-EO was $1200 \mathrm{~g} / \mathrm{mol}$, and the terminal ethylene oxide sequences consisted of one unit. The $M_{\mathrm{n}}$ of the prepolymer HP-PDMS was 960 g/mol. 4,4'-Methylenediphenyl diisocyanate (MDI), purchased from Aldrich, with an isocyanate content 33.6 wt.\%, was used as received [9]. Commercially available Boltorn ${ }^{\circledR}$ hydroxy-functional aliphatic hyperbranched polyester of the second $(\mathrm{BH}-20)$ pseudo- generation was kindly supplied by Perstorp Specialty Chemicals $A B$ (Sweden) and dried at $50{ }^{\circ} \mathrm{C}$ under vacuum for two days prior to use. $\mathrm{BH}-20$ was synthesized in an acid-catalyzed polyesterification from the 2,2-bis(hydroxymethyl)propionic acid and a tetrafunctional ethoxylated pentaerythrytol, using pseudo onestep procedure [19]. From the number average molecular weight, determined by vapor pressure osmometry $\left(M_{\mathrm{n}}=1340 \mathrm{~g} / \mathrm{mol}\right)$, and hydroxyl number, determined by titration method (501.1 $\mathrm{mg} \mathrm{KOH} / \mathrm{g}$ ), functionality of $\mathrm{BH}-20$ was calculated $(f=12)$ [20]. The catalyst stannous octanoate $\left(\mathrm{Sn}(\mathrm{Oct})_{2}\right.$, from Aldrich) was used as diluted solution in anhydrous $\mathrm{N}$-methyl-2-pyrrolidone (NMP). NMP was supplied by Acros, distilled under vacuum before use. Tetrahydrofuran (THF) was purchased from J. T. Baker, dried over lithium aluminum hydride and distilled before use.

\section{Synthesis of polyurethane films}

Two series of polyurethanes (series PUS-EO and PUS-HP) were synthesized by a two-step polymerization in solution, using mixture NMP/THF as solvent and stannous octanoate as catalyst. For the samples of the series PUS-EO, the prepolymer was EO-PDMS-EO, while for the samples of the series PUS-HP it was HP-PDMS. Crosslinking agent for both series was $\mathrm{BH}-20$. Series PUS-EO (PUS-EO15, PUS-EO30 and PUS-EO60), and series PUS-HP (PUS-HP15, PUS-HP30 and PUS-HP70) were consisted of three samples of different soft segment content. The last two numbers in the name of the PUs denote the weight percent of the soft segment (EO-PDMS-EO or PDMS-HP).

All PU networks were synthesized in the similar manner under the optimal polymerization conditions [9]: the molar ratio of $\mathrm{NCO} / \mathrm{OH}$ groups was $1.05 / 1$, the amount of the catalyst $\mathrm{Sn}(\mathrm{Oct})_{2}$ was $0.15 \mathrm{~mol} . \%$ calculated on the amount of prepolymer (i.e., ca. 0.02 wt.\% in the polyurethane), while a mixture of NMP/THF $(7 / 1, v / v)$ was employed as the solvent. Reactions were carried out in a four-neck round-bottom flask equipped with a mechanical stirrer, an argon inlet, a reflux condenser and an addition funnel. Calculated amounts of prepolymer and MDI were weighted into the reaction flask at room temperature, dissolved in the mixture of $\mathrm{NMP} / \mathrm{THF}$ and then heated up to $40{ }^{\circ} \mathrm{C}$ under an argon atmosphere. The reaction was started by the introduction of $\mathrm{Sn}(\mathrm{Oct})_{2}$. The reaction mixture was stirred for $30 \mathrm{~min}$ (for PUS-EO series) or $20 \mathrm{~min}$ (for PUS-HP series) at $40{ }^{\circ} \mathrm{C}$ to prepare the NCO-terminated prepolymer, when the theoretical NCO content was attained [9]. The NCO content was controlled by dibutylamine back-titration method [21]. In the second stage of reaction, dilute solution of $\mathrm{BH}-20$ in NMP was added drop-wise to the NCO-terminated prepolymer and reaction was continued at $40{ }^{\circ} \mathrm{C}$ for $10 \mathrm{~min}$. Finally, the obtained reaction mixture was cast into a Teflon ${ }^{\circledR}$ 
mold. The crosslinking reaction was continued in a force-draft oven during $40 \mathrm{~h}$ at $80^{\circ} \mathrm{C}$ and $1 \mathrm{~h}$ at $110{ }^{\circ} \mathrm{C}$, and finally $10 \mathrm{~h}$ at $50{ }^{\circ} \mathrm{C}$ in a vacuum oven. The thickness of the obtained yellow films was about $1 \mathrm{~mm}$.

\section{Characterization}

Dynamic mechanical thermal analyses (DMTA) of the PU films were performed on an ARES G2 rheometer (TA Instruments) at a frequency of $1 \mathrm{~Hz}$, strain $0.1 \%$, with a heating rate of $3{ }^{\circ} \mathrm{C} / \mathrm{min}$ and in the temperature range from -135 to $180{ }^{\circ} \mathrm{C}$. The measurements were carried out using rectangular specimens (16.6 mm $\times 7.5$ $\mathrm{mm} \times 1.0 \mathrm{~mm} \pm 0.2 \mathrm{~mm}$ ), under torsion mode, using torsion fixture (rectangle) geometry. Density of the PUs was measured at $20.1{ }^{\circ} \mathrm{C}$, using a pycnometer and distilled water as medium. The average of four measurements was used. The hardness measurements of the PU films were performed on a Shore A apparatus (Hildebrand, Germany). The average of at least five measurements was used.

Atomic force microscopy (AFM) was used for the evaluation of the surface topography and phase images of the fracture areas after previous freeze-fracturing of PU films at the temperature of liquid nitrogen. A commercial atomic force microscope (MultiMode Digital Instruments NanoScopeTM Dimension IIIa), equipped with the SSS-NCL probe, Super Sharp Silicon ${ }^{\text {TM }}$-SPM-Sensor (NanoSensors ${ }^{\mathrm{TM}}$ Switzerland; spring constant, $\approx 35 \mathrm{~N} / \mathrm{m}$, resonant frequency, $\approx 170 \mathrm{kHz}$ ) was used. Measurements were performed under ambient conditions using the tapping mode AFM technique.

Small-angle $\mathrm{X}$-ray scattering (SAXS) experiments were performed using a 3 pinhole camera (Molmet/Rigaku), attached to a multilayer aspherical optics (Osmic Confocal Max-Flux), which monochromatizes and con- centrates the beam of a microfocus X-ray tube (Bede) operating at $45 \mathrm{kV}$ and $0.66 \mathrm{~mA}(30 \mathrm{~W})$. The camera had a multiwire, gas-filled 2D detector with $0.2 \mathrm{~m}$ diameter of an active area (Gabriel design).

Scanning electron microscopy (SEM) micrographs of the PUs were obtained on a JEOL JSM-6610 microscope.

Water absorption (WA) of the PUs was determined by immersing the films in distilled water for $48 \mathrm{~h}$ at room temperature. The water absorption of the films was calculated as follows: $\left(w-w_{0}\right) \times 100 / w_{0}$, where $w$ is the weight of wet and $w_{0}$ is the weight of the dry sample.

\section{RESULTS AND DISCUSSION}

Two series of PU networks based on ethylene oxidepoly(dimethylsiloxane)-ethylene oxide or hydroxypropyl-poly(dimethylsiloxane) as the soft segments, 4,4'-methylenediphenyl diisocyanate and hyperbranched polyester of the second pseudogeneration as the hard segment, were synthesized by two-step polymerization in solution. Two-step polymerization in solution was applied to improve the compatibility between reactants during the synthesis of PUs, using the mixture NMP/ /THF as a reaction medium. The content and type of soft segment were varied in order to investigate the influence of these variables on the morphology and properties of the synthesized PU networks.

The influences of the type and content of soft segments on the viscoelastic properties of PU networks were investigated by dynamic mechanical thermal analysis of samples. The storage shear modulus, $G^{\prime}$, and the mechanical loss factor, $\tan \delta$, of PU samples as function of temperature are displayed in Figure 1. DMTA results

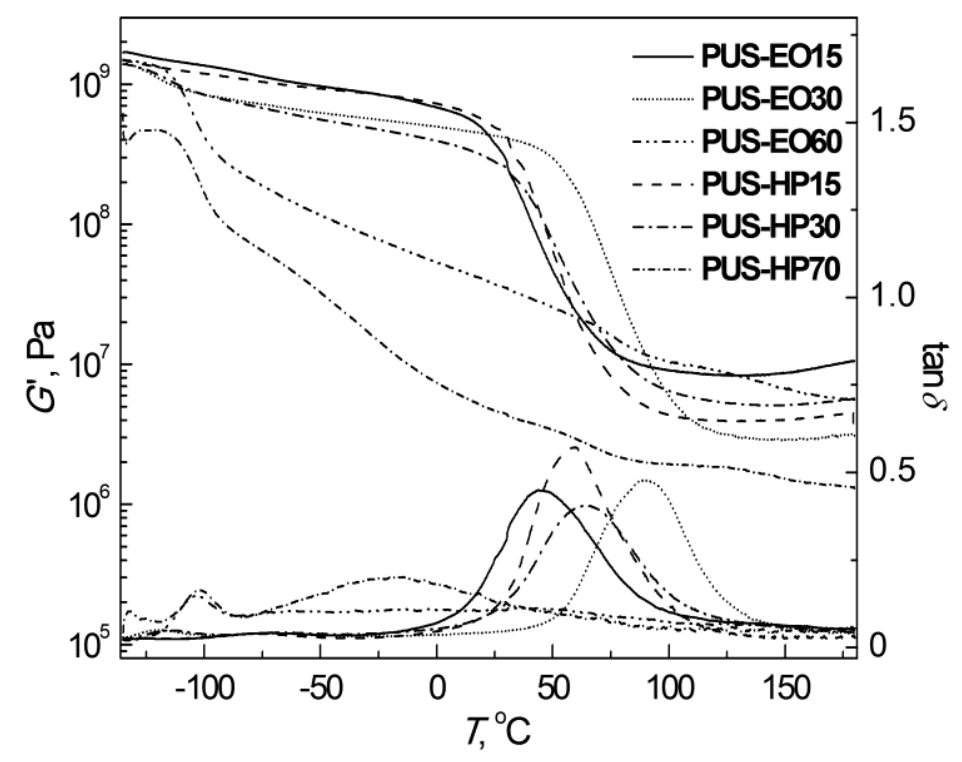

Figure 1. Storage modulus $\left(G^{\prime}\right)$ and tan $\delta$ of the synthesized PUs versus temperature. 
are summarized in Table 1 . The dynamic mechanical behavior illustrates the microphase separated morphology of the synthesized PUs. The PU networks have two glass transition temperatures, of the soft and hard segments, and one secondary relaxation process. Tan $\delta \mathrm{vs}$. temperature dependences of samples show glass transition in the temperature region from -126 to $-102{ }^{\circ} \mathrm{C}$ for samples of both series, associated with the soft PDMS segment $\left(T_{\mathrm{gss}}\right)$. This peak does not change its position by changing the type of PDMS macrodiols, while $T_{\mathrm{gss}}$ decreases with decreasing PDMS content, indicating better microphase separation with decreasing PDMS content. The obtained results showed a relatively small increase of $T_{\mathrm{gss}}$ for samples with higher PDMS content in comparison to the PDMS prepolymer $\left(-123^{\circ} \mathrm{C}\right)$ [3], indicating a certain degree of segmental mixing in PUs. In addition to this, the sample PUS-EO60 has aditional relaxation peak at $-9{ }^{\circ} \mathrm{C}$ assigned to the movement of etoxypropyl end PDMS groups [22]. For other investigated PUs this transition was not visible, indicating that movement of PDMS end groups is restricted by the presence of crosslinks and hard MDI-HBP segments. DMTA results show that dynamic mechanical properties of PUS-EO60 and PUS-HP70 are different in comparison with other investigated PUs (Figure 1). As shown in Figure 1, the storage modulus of PUS-EO60 and PUS-HP70 gradually decreases, due to the very low degree of chemical crosslinking of these two PU samples. The DMTA curves show a small maximum in $\tan \delta$ $\left(T_{2}\right)$ in the temperature region from -74 to $-59^{\circ} \mathrm{C}$ (PUSEO series) and from -79 to $-17{ }^{\circ} \mathrm{C}$ (PUS-HP series), which corresponds to the subglass relaxation process. This is probably a consequence of the movement of the part of chain which contains urethane groups connected to the Boltorn ${ }^{\circledR}$ HBP [13]. Due to the steric hindrance, these urethane groups are not involved in the formation of hydrogen bonds and are therefore more mobile. The temperatures associated with the second relaxation process increase with increasing PDMS content in both series and values of $T_{2}$ are higher for samples of PUS-HP series. The glass transition temperature of the hard (MDI-HBP) segment $\left(T_{\mathrm{gHS}}\right)$ was detected from $\tan \delta$ curves in the temperature region from 40 to
$90{ }^{\circ} \mathrm{C}$ (PUS-EO series) and from 58 to $60{ }^{\circ} \mathrm{C}$ (PUS-HP series). Generally, the values of $T_{\mathrm{gHS}}$ are higher for samples in PUS-HP series. From the obtained DMTA results, it can be concluded that, the change in the $T_{\mathrm{gHS}}$ values of the synthesized PUs indicates changes in the degree of phase separation. It can be concluded that PU samples of PUS-HP series have higher degree of microphase separation than samples of PUS-EO series, as a result of higher incompatibility between the hydroxypropyl terminated PDMS and the urethane components (MDI and $\mathrm{BH}-20$ ). During the synthesis of $\mathrm{PU}$ samples based on EO-PDMS-EO, EO blocks act as compatibilizers between non-polar PDMS prepolymer and urethane reactants. Therefore, the presence of terminal EO blocks in PDMS prepolymer improves miscibility between reactants and PU samples based on EO-PDMSEO have lower $T_{\mathrm{gHS}}$ values and consequently lower degree of microphase separation. In the $\tan \delta$ temperature dependence of PUS-EO60 and PUS-HP70, the presence of broader peaks also implies that miscibility of the network components is better than in other synthesized samples. Samples PUS-EO3O and PUS-HP3O have the highest values of $T_{\mathrm{gHS}}$ in both series, due to the highest crosslinking density (Table 1). The reason for higher crosslinking density of samples with 30 wt.\% of soft segment in both series in comparison with samples containing 15 wt.\% of soft segment may be steric hindrance caused by HBP molecules, which is more pronounced in samples with $15 \mathrm{wt} \%$ of soft segment because of higher amount of $\mathrm{BH}-20$. Therefore, instead of participating in the reaction of crosslinking, $-\mathrm{OH}$ groups of the HBPs may be hydrogen bonded. It can be concluded that the glass transition temperature of the PU networks is influenced by the crosslinking density, the content and type of soft segments and by mutual miscibility between components.

DMTA analysis is a quick and direct method for the determination of crosslinking density of the synthesized PUs. The crosslinking density of the synthesized PU networks can be calculated from the rubber elasticity theory using equation (1), by assuming the absence of entanglements and that the synthesized PUs exhibit affine behavior where chains and crosslinks

Table 1. Temperatures corresponding to the tan $\delta$ maximum, cross-linking density, $v$, molecular weight of polymer chain between cross-links, Mc, values of the ratio Ts/TgH(tan $\delta$ ), hardness and water absorption, WA, of the synthesized PUs

\begin{tabular}{|c|c|c|c|c|c|c|c|c|}
\hline \multirow{2}{*}{ Sample } & \multicolumn{3}{|c|}{$\tan \delta$} & \multirow{2}{*}{$\begin{array}{c}v \times 10^{4} \\
\mathrm{~mol} / \mathrm{cm}^{3}\end{array}$} & \multirow{2}{*}{$\begin{array}{c}M_{\mathrm{c}} \\
\mathrm{g} / \mathrm{mol}\end{array}$} & \multirow{2}{*}{$\begin{array}{l}T_{\mathrm{s}} / T_{\mathrm{gHS}} \\
(\tan \delta) \\
\end{array}$} & \multirow{2}{*}{ Hardness Shore A } & \multirow{2}{*}{ WA / \% } \\
\hline & $T_{\mathrm{gSS}} /{ }^{\circ} \mathrm{C}$ & $T_{2} /{ }^{\circ} \mathrm{C}$ & $T_{\mathrm{gHS}} /{ }^{\circ} \mathrm{C}$ & & & & & \\
\hline PUS-EO15 & -126 & -74 & 46 & 26.23 & 415 & 0.414 & 91 & 5.7 \\
\hline PUS-EO30 & -120 & -69 & 90 & 8.19 & 1280 & 0.572 & 88 & 3.0 \\
\hline PUS-EO60 & -102 & -59 & 40 & - & - & - & 85 & 1.3 \\
\hline PUS-HP15 & -126 & -79 & 60 & 11.85 & 937 & 0.463 & 93 & 7.2 \\
\hline PUS-HP30 & -114 & -63 & 65 & 15.33 & 732 & 0.486 & 91 & 2.3 \\
\hline PUS-HP70 & -102 & -17 & 58 & 4.92 & 2368 & 0.883 & 88 & 1.6 \\
\hline
\end{tabular}


move proportionally to the macroscopic deformation, due to the high functionality and presence of the steric hindrance $[23,24]$.

$v=\frac{G^{\prime}}{R T}$

where $G^{\prime}$ represents the rubbery plateau modulus at $T$ $=\left(T_{\mathrm{gH}}\right)_{G^{\prime \prime}}+90{ }^{\circ} \mathrm{C}$ and $\left(T_{\mathrm{gH}}\right)_{G^{\prime \prime}}$ is the glass transition temperature of the hard segments determined from the loss modulus ( $\left.G^{\prime \prime}\right)$ maximum. Value of the molecular weight of polymer chain between crosslinks, $M_{c}$, was evaluated as:

$M_{\mathrm{c}}=\frac{\rho_{\mathrm{PU}}}{v}$

where $\rho_{\mathrm{PU}}$ is the density of PU samples, which is between 1.050 and $1.096 \mathrm{~g} / \mathrm{cm}^{3}$ for PUS-EO samples, and between 1.110 and $1.165 \mathrm{~g} / \mathrm{cm}^{3}$ for PUS-HP samples.

The estimated values for $v$, given in Table 1, generally decrease with an increase of the soft segment content, except for PUS-EO30 and PUS-HP30 samples, which have the highest crosslinking density. The values of the $M_{c}$, listed in Table 1, are inversely proportional to the crosslinking density. The increase of the crosslinking density increased hardness from 85 to 91 Shore A (PUS-EO series), and from 88 to 93 Shore A (PUS-HP series). Hardness of PU samples of PUS-HP series is higher than for PU samples of PUS-EO series.

Value of the ratio between softening point, determined as the onset of the log $G^{\prime}$ drop in the glass transition region of the MDI-HBP segments (Figure 1 ), and $T_{\mathrm{gH}}(\tan \delta)$, represents a measure of the width of $\tan \delta$ peak which corresponds to the glass transition of the hard segments [14]. From Table 1 it can be observed that, as the soft segment content decreases, value of $T_{\mathrm{s}} / T_{\mathrm{gH}}(\tan \delta)$ also decreases and a broadening of $\tan \delta$ peak occurs, indicating that different lengths of the chains between crosslinks are formed.

From DMTA results, values of $G^{\prime}$ for PU networks are higher than values of the loss modulus (not presented) in the whole investigated temperature region. This observation indicates that cohesion and stability of the PU networks is not destroyed and that PU samples show elastic properties under investigated experimental conditions. At lower temperatures, the value of $G^{\prime}$ increases with increasing hard segment content, while in the temperature region from 20 to $100{ }^{\circ} \mathrm{C}$ there is reduction in $G^{\prime}$ values due to the increased mobility of chains caused by the glass transition of hard segments. After that, the value of $G^{\prime}$ again increases in the rubbery plateau region at around $150{ }^{\circ} \mathrm{C}$ with increasing hard segment content, indicating a simultaneous increase of crosslinking density. It can be observed (Figure 1) that the rubbery plateau modulus of the investigated PU networks is higher than the values obtained for other crosslinked polyurethane based on hydroxybutylPDMS [25] and for PUs based on poly(propylene oxide) and Boltron ${ }^{\circledR}$ HBP [14]. Therefore, the incorporation of the EO-PDMS-EO or HP-PDMS into PU networks based on $\mathrm{BH}-20$ as crosslinker improved the thermomechanical properties of the polymer.

PU samples containing different amount of soft segments and synthesized with different PDMS type were analyzed by AFM. In order to obtain the "bulk" information, surface areas of freeze-frozen samples were studied. The results are given in Figures 2 (3D height images) and 3 (2D phase images). Based on prior studies, it is known that the bright regions represent the hard phase (hard ordered domains in a polyurethane), while the darker regions represent the soft phase. Height images, showing surface topography, substantially differ for PUs containing different soft segment content: PUS-EO30 and PUS-HP15 sample have smooth "chain-like" relief (PUS-HP15 is the smoothest one), while the topographies of PUS-EO60 and PUS-HP30 samples show agglomerates of $\mu \mathrm{m}$ size (PUS-EO60 is the roughest one). Roughness, $R_{\mathrm{q}}$, values for all samples are given in Table 2 . The samples with higher $R_{\mathrm{q}}$ values have rougher surface. Therefore, the sample PUS-HP30 has rougher surface than PUS-EO30.

Phase images (i.e., maps of tip-sample interactions) enable qualitative insight into the sample homogeneity relief. 2D AFM pictures of phase images are given in Figure 3. It is evident that the PU samples are distinguished by heterogeneous character, apparently connected with strong microphase separation. Sample PUS-HP15 is the most homogeneous, and samples PUS-EO30, PUS-EO60 and PUS-HP30 are heterogeneous either on $\mathrm{nm}$ (PUS-EO30) or even on $\mu \mathrm{m}$ level (PUS-EO60 and PUS-HP30).

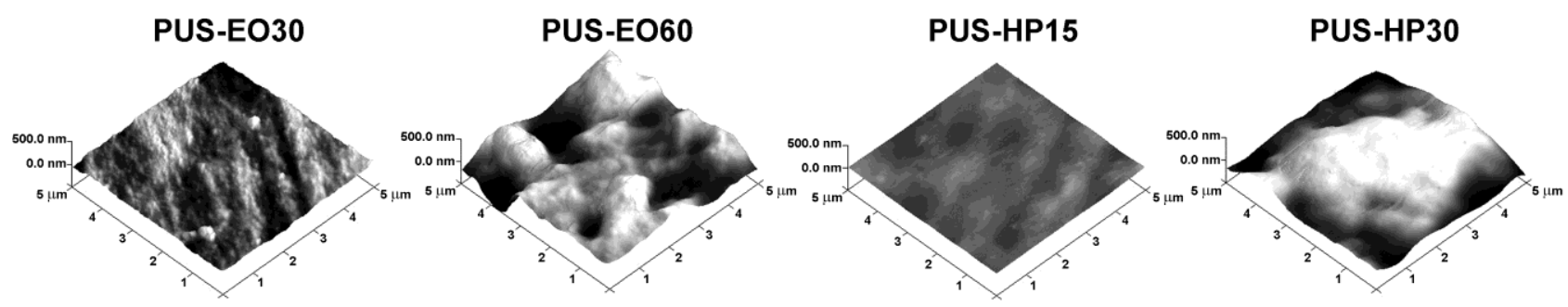

Figure 2. 3D AFM images of frozen PU samples (scans $5 \times 5 \mu \mathrm{m}^{2}, \mathrm{z}$-scale $500 \mathrm{~nm}$ in all cases). 

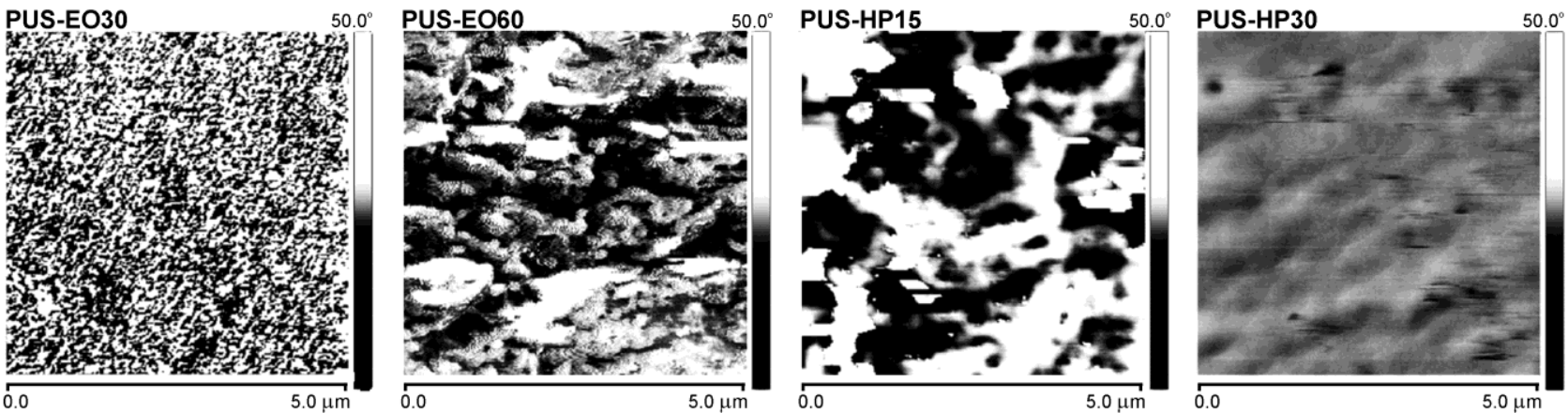

Figure 3. 2D AFM phase images of frozen PU samples (scans $5 \times 5 \mathrm{\mu m}^{2}, \mathrm{z}$-scale $50^{\circ}$ in all cases).

Table 2. Roughness values and SAXS interdomain spacing, D, of PU samples; Surface area: the total area of examined sample surface (the three-dimensioned area ofa given region expressed as the sum of the area of all the triangles formed by three adjacent data points)

\begin{tabular}{lccccc}
\hline Sample & Surface area, $\mu \mathrm{m}^{2}$ & $R_{\mathrm{q}}{ }^{\mathrm{a}} / \mathrm{nm}$ & $R_{\mathrm{a}}{ }^{\mathrm{b}} / \mathrm{nm}$ & $R_{\max }{ }^{\mathrm{c}} / \mathrm{nm}$ & 213 \\
\hline PUS-EO30 & 26.2 & 25 & 20 & 829 & 10.5 \\
PUS-EO60 & 29.0 & 141 & 108 & 44 & 8.1 \\
PUS-HP15 & 25.1 & 6 & 5 & 741 & 12.1 \\
PUS-HP30 & 26.8 & 161 & 133 & 11.0 \\
\hline
\end{tabular}

${ }^{a}$ (RMS) The standard deviation of the $Z$ values within the given area.; (mean roughness): the mean value of the surface relative to the center place; ${ }^{c}$ (max height): the difference in height between the highest and lowest points on the surface relative to the mean plane; mean: the average of all $Z$ values within the enclosed area; ${ }^{d}$ interdomain spacing of PUS-HP70 is $5.9 \mathrm{~nm}$

The microphase separated morphology of the synthesized PU networks was confirmed by SAXS analysis. SAXS profiles of PU samples are shown in Figure 4. The results (except for the sample PUS-HP70) showed the presence of well-defined scattering peaks, indicating the presence of a microphase separated morphology under ambient conditions. According to the SAXS data, sample PUS-HP70 exhibits a broad scattering peak, suggesting the greater phase-mixing in comparison with other synthesized PUs. The average interdomain spacings in the PU samples were calculated from the position of the interference peaks in the respective scattering intensity profiles of the samples according to Bragg's law, $D=2 \pi / q$, where $q$ is the scattering vector. The values of interdomain spacing are listed in Table 2 . As expected, the interdomain spacing was found to decrease with an increase of the soft segment content. As the hard segment content increases, while keeping the soft segment length constant, the center-to-center distance between the hard domains increases as shown by the SAXS results. The value of interdomain spacing of hard segments is $10.5 \mathrm{~nm}$ for PUS-EO30 and $11.0 \mathrm{~nm}$ for PUS-HP30. The obtained results showed that interdomain spacing of hard segments depend on the soft segment content but not on the soft segment structure (Table 2). The interdomain spacing of hard segments is of the same order as those often found for polyurethanes presented in literature [26]. According to the Figure 4 , the larger increase of the scattering intensity for PUS-HP30 can be related to the presence of better microphase separated structures in comparison with the sample PUS-EO30. Analysis of the SAXS profiles at higher values of scattering vector $\left(q>q_{\max }\right)$ shows that the scattering intensity, $I(q)$, changes as follows: $I(q) \sim q^{-n}$. For the PUS-EO30, PUS-HP15 and PUS-HP30, scattering intensity follows Porod's law, i.e., $I(q) \sim q^{-4}$, which is typical of well-microphase separated structures with clear boundaries between phases $[27,28]$. On the other hand, for samples PUS-EO60 and PUS-HP70 values of the exponent $n$ are 1.7 and 1.1, respectively, indicating that scattering intensity for these samples decreases slower than $q^{-4}$ at high $q$ [28]. PUs which have $n$ lower than 4 have also lower degree of microphase separation according to the Velankar et al. [28].

The surface morphology of prepared films was investigated by SEM and the SEM microphotographs of the "air" surface of PU samples are shown in Figure 5. The obtained results reveal existence of microphase separated morphology of PU materials. As shown in Figure 5, on the surface of sample PUS-EO30, in contrast to the PUS-HP30, the PDMS soft segments form spherical phase of about $4.5 \mu \mathrm{m}$ in diameter. According to the literature, it is possible that small amounts of polyurethane components are trapped inside the PDMS spheres [8]. The SEM microphotographs of other synthesized PUs in both series showed that the hard segments were unequally distributed in the PDMS soft segment. Microdomains of hard segments, hydrogenbonded in aggregates, irregular in shape and surrounded by EO-PDMS-EO matrix, are visible on the surface of PUS-EO60 (Figure 5). SEM results of the samples PUS-EO15 and PUS-HP15 indicate increased homoge- 


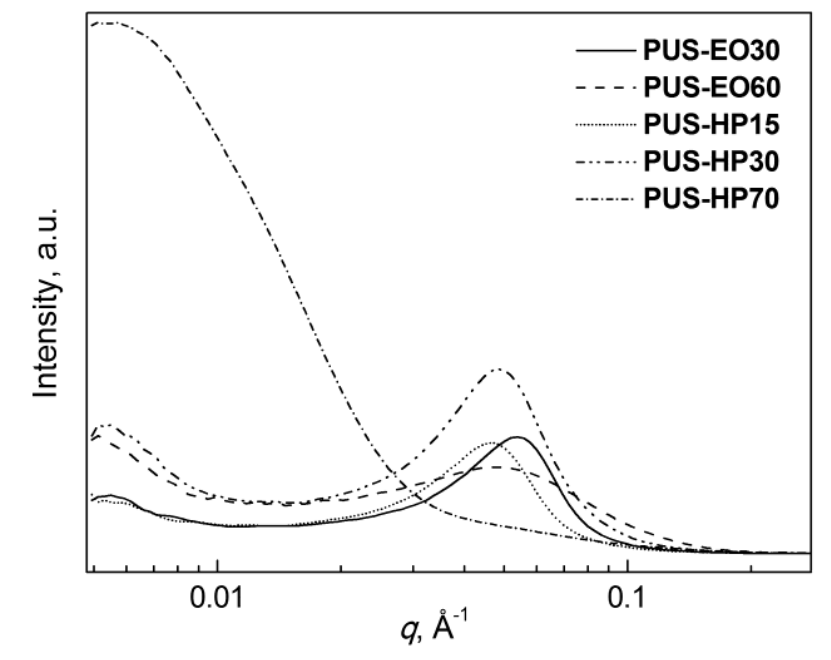

Figure 4. SAXS profiles of the synthesized PU materials.
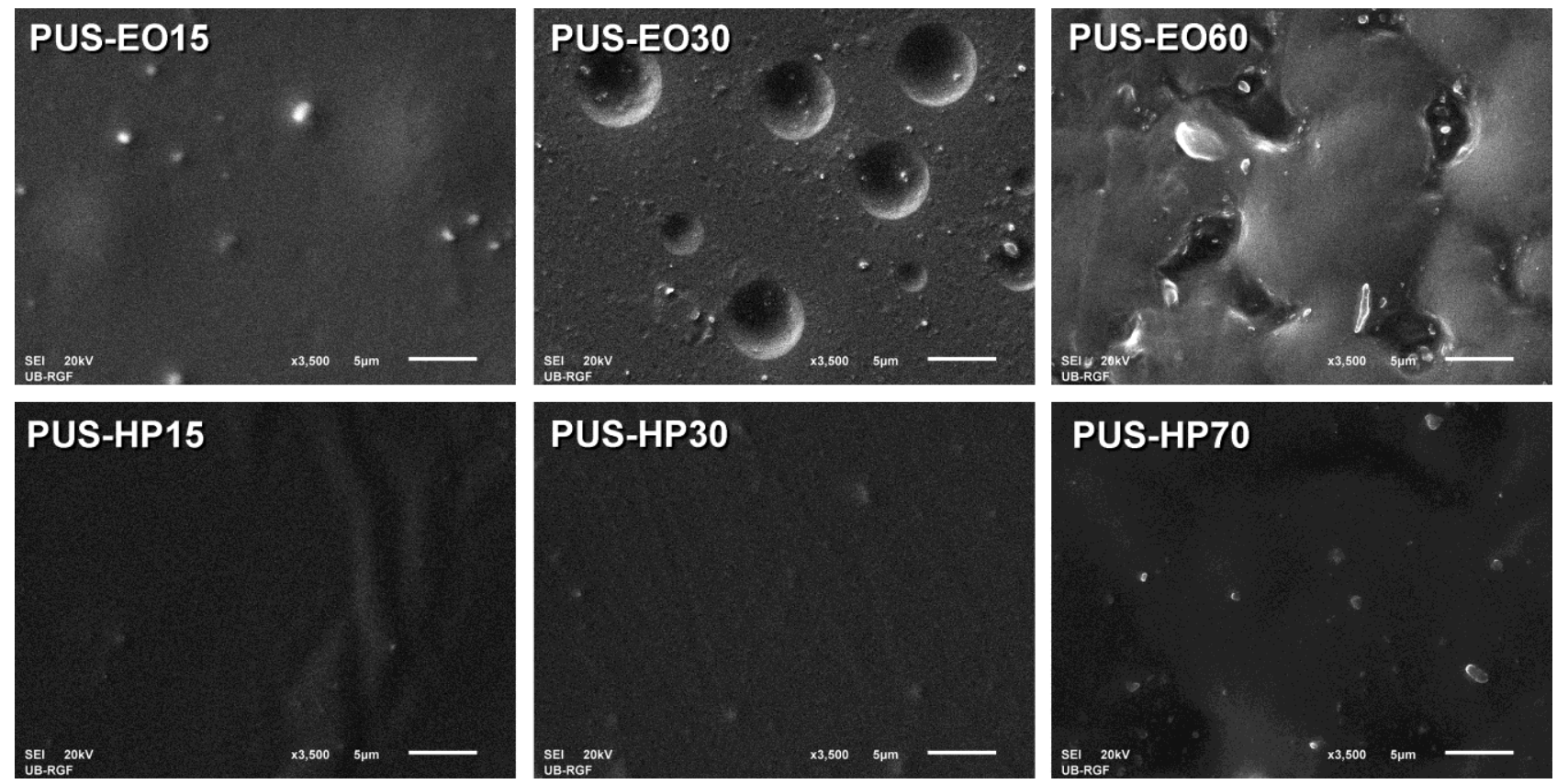

Figure 5. SEM Microphotographs of "air" surface of PU samples.

neity in samples and improved compatibility of all components. Therefore, the surface morphology of PU samples is strongly affected by the type and content of soft segments.

Water absorption was measured to determine the bulk hydrophobicity of the synthesized PUs and the obtained results are presented in Table 1 . The water absorption after $48 \mathrm{~h}$ increases with decreasing soft segment content in both series. This may be attributed to the hydrophobic character of PDMS and its surface activity. Namely, PDMS in PU networks can migrate to the surface of samples due to its lower surface energy in comparison to the surface energy of polyurethane $[3,29]$. The PUs with higher soft segment content have a more hydrophobic surface and better water resis- tance. The weight percent of the absorbed water is lower for PUS-HP samples in comparison with samples in PUS-EO series. Therefore, samples based on PDMSHP prepolymer are more hydrophobic. The water absorption in the synthesized PUs was lower than the values obtained for other PDMS based polyurethanes with comparable soft segment content [30].

\section{CONCLUSION}

Two series of polyurethane films were synthesized by two-step polymerization in NMP/THF mixture in order to investigate the effect of the type and content of PDMS soft segment on the morphology and properties of PUs. The investigated series differ in the type of functionality of terminated PDMS, which was incor- 
porated into the PU networks based on HBP as the flexible segments. In the first series, ethoxypropyl terminated PDMS was employed, while in the second hydroxypropyl terminated PDMS was used. Dynamic mechanical thermal analysis revealed existence of two glass transitions, of the soft and hard segments, and also the presence of subglass relaxation process. AFM, SAXS and SEM experiments supported DMTA results and confirmed the presence of microphase separated morphology of the synthesized PUs. The results showed that the microphase separation was more pronounced in the PU networks based on HP-PDMS, as a result of the higher incompatibility between the hydroxypropyl-PDMS prepolymer and the polar reactants, MDI and HBP. Compared with EO-PDMS-EO containing polyurethanes, samples synthesized based on HP-PDMS have higher surface roughness coefficient, increased hardness, more hydrophobic surface and better waterproof performance. The results showed increase of crosslinking density, improvement of thermomechanical properties and less hydrophobicity with decreasing the soft segment content. The obtained results indicate that the synthesis of poly(urethane-siloxane) based on HBP leads to creation of materials with good thermomechanical and surface properties, which can be easily tailored by changing the type of PDMS prepolymer or the content of soft segments.

\section{Acknowledgements}

This work was financially supported by the Ministry of Education, Science and Technological Development of the Republic of Serbia (Project No. 172062) and Czech Science Foundation (GACR, Project No. P108/10/0195).

\section{REFERENCES}

[1] J. Dodge, in: M.E. Rogers, T.E. Long (Eds.), Synthesis Methods in Step-Growth Polymers, Wiley, Hoboken, NJ, 2003, pp. 197-214.

[2] D.K. Chattopadhyay, K.V.S.N. Raju, Structural engineering of polyurethane coatings for high performance applications, Prog. Polym. Sci. 32 (2007) 352-418.

[3] I. Yilgör, J. McGrath, Polysiloxane Containing Copolymers: A Survey of Recent Developments, Adv. Polym. Sci. 86 (1988) 1-86.

[4] P.R. Dvornić, R.W. Lenz, High Temperature Siloxane Elastomers, Hüthing Wepf, Heidelberg, New York, 1990.

[5] M.V. Pergal, V.V. Antić, S. Ostojić, M. Marinović-Cincović, J. Djonlagić, Influence of the content of hard segments on the properties of novel urethane-siloxane copolymers based on a poly( $\varepsilon$-caprolactone)- $b$-poly(dimethylsiloxane)-b-poly( $\varepsilon$-caprolactone) triblock copolymer, J. Serb. Chem. Soc. 76 (2011) 1703-1723.

[6] M.V. Pergal, V.V. Antić, G. Tovilović, J. Nestorov, D. Vasiljević-Radović, J. Djonlagić, In vitro biocompatibility evaluation of novel urethane-siloxane copolymers based on poly( $\varepsilon$-caprolactone)-block-poly(dimethylsiloxane)-block-poly(e-caprolactone), J. Biomater. Sci. Polym., E 23 (2012) 1629-1657.

[7] J.P. Sheth, A. Aneja, G.L. Wilkes, E. Yilgor, G.E. Atilla, I. Yilgor, F.L. Beyer, Influence of system variables on the morphological and dynamic mechanical behavior of polydimethylsiloxane based segmented polyurethane and polyurea copolymers: a comparative perspective. Polymer 45 (2004) 6919-6932.

[8] P. Majumdar, D.C. Webster, Preparation of siloxaneurethane coatings having spontaneously formed stable biphasic microtopograpical surfaces, Macromolecules 38 (2005) 5857-5859.

[9] M.V. Pergal, V.V. Antic, M.N. Govedarica, D. Gođevac, S. Ostojić, J. Djonlagic, Synthesis and characterization of novel urethane-siloxane copolymers with a high content of PCL-PDMS-PCL segments, J. Appl. Polym. Sci. 122 (2011) 2715-2730.

[10] A. Stanciu, V. Bulacovschi, V. Condratov, C. Fadei, A. Stoleriu, S. Balint, Thermal stability and the tensile properties of some segmented poly(ester-siloxane)urethanes, Polym. Degrad. Stab. 64 (1999) 259-265.

[11] E. Žagar, M. Žigon, Aliphatic Hyperbranched polyesters based on 2,2-bis(methylol)propionic acid - Determination of structure, solution and bulk properties, Prog. Polym. Sci. (Oxford) 36 (2011) 53-88.

[12] P.K. Maji, A.K. Bhowmick, Influence of number of functional groups of hyperbranched polyol on cure kinetics and physical properties of polyurethanes, J. Polym. Sci. Part A Polym. Chem. 47 (2009) 731-745.

[13] P. Czech, L. Okrasa, J. Ulanski, G. Boiteux, F. Mechin, P. Cassagnau, Studies of the molecular dynamics in polyurethane networks with hyperbranched crosslinkers of different coordination numbers, J. Appl. Polym. Sci. 105 (2007) 89-98.

[14] A. Asif, W. Shi, X. Shen, K. Nie, Physical and thermal properties of UV curable waterborne polyurethane dispersions incorporating hyperbranched aliphatic polyester of varying generation number, Polymer 46 (2005) 11066-11078.

[15] M.V. Pergal, J.V. Džunuzović, M. Kićanović, V. Vodnik, M.M. Pergal, S. Jovanović, Thermal properties of poly(urethane-ester-siloxane)s based on hyperbranched polyester, Russ. J. Phys. Chem., A 85 (2011) 2251-2256.

[16] M.V. Pergal, J.V. Džunuzović, S. Ostojić, M.M. Pergal, A. Radulović, S. Jovanović, Poly(urethane-siloxane)s based on hyperbranched polyester as crosslinking agent: synthesis and characterization, J. Serb. Chem. Soc. 77 (2012) 919-935.

[17] J.V. Džunuzović, M.V. Pergal, R. Poręba, S. Ostojić, N. Lazić, M. Špírková, S. Jovanović, Studies of the thermal and mechanical properties of poly(urethane-siloxane)s cross-linked by hyperbranched polyesters, Ind. Eng. Chem. Res. 51 (2012) 10824-10832.

[18] J.V. Džunuzović, M.V. Pergal, R. Poręba, V.V. Vodnik, B.R. Simonović, M. Špírková, S. Jovanović, Analysis of dynamic mechanical, thermal and surface properties of poly(urethane-ester-siloxane) networks based on hyper- 
branched polyester, J. Non-Cryst. Solids 358 (2012) 3161.

[19] E. Malmström, M. Johansson, A. Hult, Hyperbranched aliphatic polyesters, Macromolecules 28 (1995) 1698$-1703$.

[20] J. Vuković, Synthesis and characterization of aliphatic hyperbranched polyesters, PhD thesis, Univerzitet $u$ Osnabrück-u, Nemačka, 2006., http://www.dart-europe.eu/full.php?id=36706

[21] Å. Marand, J. Dahlin, D. Karlsson, G. Skarping, M. Dalene, Determination of technical grade isocyanates used in the production of polyurethane plastics, J. Environ. Monit. 6 (2004) 606-614.

[22] R. Hernandez, J. Weksler, A. Padsalgikar, J. Runt, Microstructural organization of three-phase polydimethylsiloxane-based segmented polyurethanes, Macromolecules 40 (2007) 5441-5449.

[23] B.S. Chiou, P.E. Schoen, Effects of crosslinking on thermal and mechanical properties of polyurethanes, J. Appl. Polym. Sci. 83 (2002) 212-223.

[24] L. Vallete, C.-P. Hsu, Polyurethane and unsaturated polyester hybrid networks: 2 . Influence of harddomains on mechanical properties, Polymer 40 (1999) 2059-2070 .
[25] M. Alexandru, M. Cazacu, M. Cristea, A. Nistor, C. Grigoras, B.C. Simionescu, Poly(siloxane-urethane) crosslinked structures obtained by sol-gel technique, J. Polym. Sci., B 49 (2011) 1708-1718.

[26] J.T. Koberstein, R.S. Stein, Small-angle X-ray scattering studies of microdomain structure in segmented polyurethane elastomers, J. Polym. Sci., B 21 (1983) 1439$-1472$.

[27] I. Krakovský, Z. Bubeníková, H. Urakawa, K. Kajiwara, Inhomogeneous structure of polyurethane networks based on poly(butadiene)diol: 1 . The effect of the poly(butadiene)diol content, Polymer 38 (1997) 3637-3643.

[28] S. Velankar, S.L. Cooper, Microphase separation and rheological properties of polyurethane melts. 2. Effect of block incompatibility on the microstructure, Macromolecules 33 (2000) 382-394.

[29] H.D. Hwang, H.J. Kim, Enhanced thermal and surface properties of waterborne UV-curable polycarbonatebased polyurethane (meth)acrylate dispersion by incurporation of polydimethylsiloxane, React. Funct. Polym. 71 (2011) 655-665.

[30] Y.H. Lee, E.J. Kim, H.D. Kim, Synthesis and properties of waterborne poly(urethane urea)s containing polydimethylsiloxane, J. Appl. Polym. Sci. 120 (2011) 212-219.

\title{
IZVOD
}

\section{PROUČAVANJE MORFOLOGIJE I TERMOMEHANIČKIH SVOJSTAVA UMREŽENIH POLI(URETAN-SILOKSANA) NA BAZI HIPERRAZGRANATOG POLIESTRA}

\author{
Marija V. Pergal ${ }^{1}$, Jasna V. Džunuzović ${ }^{1}$, Milena Špírková ${ }^{2}$, Rafał Poręba $^{2}$, Miloš Steinhart ${ }^{3}$, Miodrag M. Pergal ${ }^{4}$, \\ Sanja Ostojićs \\ ${ }^{1}$ Institut za hemiju, tehnologiju i metalurgiju (IHTM)-Centar za hemiju, Univerzitet u Beogradu, Beograd, Srbija \\ ${ }^{2}$ Institute of Macromolecular Chemistry AS CR, v.v.i. (IMC), Nanostructured Polymers and Composites Department, \\ Prague, Czech Republic \\ ${ }^{3}$ Institute of Macromolecular Chemistry AS CR, v.v.i. (IMC), Supramolecular Polymer Systems Department, Prague, \\ Czech Republic \\ ${ }^{4}$ Hemijski fakultet, Univerzitet u Beogradu, Beograd, Srbija \\ ${ }^{5}$ Institut za opštu i fizičku hemiju, Univerzitet u Beogradu, Beograd, Srbija
}

(Naučni rad)

$\mathrm{U}$ ovom radu pripremane su dve serije poliuretanskih filmova na bazi hiperraz granatog poliestra druge pseudo generacije $\left(\right.$ Boltron $^{\circledR}$ ), 4,4'-metilendifenildiizocijanata i dva različita siloksanska pretpolimera kao što su $\alpha, \omega$-dihidroksi(etilenoksid-poli(dimetilsiloksan)-etilenoksid) (EO-PDMS-EO) i $\alpha, \omega$-dihidroksipropil-poli(dimetilsiloksan) (HP-PDMS), dvostepenom polimerizacijom u rastvoru. Uticaj vrste i sadržaja mekog segmenta na morfologiju, termomehanička i površinska svojstva sintetisanih poliuretana je proučavan pomoću mikroskopije atomske sila (AFM), rasipanja X-zraka pod malim uglovima (SAXS), skenirajuće elektronske mikroskopije (SEM), dinamičko mehaničke termičke analize (DMTA) i merenja količine apsorbovane vode. Nađeno je da primenjene tehnike potvrđuju postojanje morfologije mikrofaznog razdvajanja. Sintetisani poliuretani pokazivali su dve temperature ostakljivanja i jedan sekundarni relaksacioni proces. Rezultati su pokazali da poliuretani na bazi HP-PDMS su imali veći koeficijent hrapavosti, bolje mikrofazno razdvajanje i bolju otpornost prema vodi. Uzorci sintetisani sa nižim sadržajem PDMS-a su imali manju hidrofobnost, ali veću gustinu umrežavanja i bolja termomehanička svojstva.
Ključne reči: Umreženi poliuretani • Poli(dimetilsiloksan)• Hiperrazgranati poliestar • Morfologija • Termomehanička svojstva 